\title{
Sex-associated variations in coral skeletal oxygen and carbon isotopic composition of Porites panamensis in the southern Gulf of California
}

\author{
Rafael A. Cabral-Tena ${ }^{1}$, Alberto Sánchez ${ }^{2}$, Héctor Reyes-Bonilla ${ }^{3}$, Angel H. Ruvalcaba-Díaz ${ }^{2}$, and Eduardo F. Balart ${ }^{1}$ \\ ${ }^{1}$ Centro de Investigaciones Biológicas del Noroeste (CIBNOR), La Paz, Baja California Sur 23096, Mexico \\ ${ }^{2}$ Centro Interdisciplinario de Ciencias Marinas-Instituto Politécnico Nacional (CICIMAR-IPN), La Paz, \\ Baja California Sur 23096, Mexico \\ ${ }^{3}$ Departamento de Biología Marina, Universidad Autónoma de Baja California Sur (UABCS), La Paz, \\ Baja California Sur 23080, Mexico
}

Correspondence to: Eduardo F. Balart (ebalart04@cibnor.mx)

Received: 10 September 2015 - Published in Biogeosciences Discuss.: 25 November 2015

Revised: 31 March 2016 - Accepted: 18 April 2016 - Published: 10 May 2016

\begin{abstract}
Coral $\delta^{18} \mathrm{O}$ variations are used as a proxy for changes in sea surface temperature (SST) and seawater isotope composition. Skeletal $\delta^{13} \mathrm{C}$ of coral is frequently used as a proxy for solar radiation because most of its variability is controlled by an interrelationship between three processes: photosynthesis, respiration, and feeding. Coral growth rate is known to influence the $\delta^{18} \mathrm{O}$ and $\delta^{13} \mathrm{C}$ isotope record to a lesser extent than environmental variables. Recent published data show differences in growth parameters between female and male coral in the gonochoric brooding coral Porites panamensis; thus, skeletal $\delta^{18} \mathrm{O}$ and $\delta^{13} \mathrm{C}$ are hypothesized to be different in each sex. To test this, this study describes changes in the skeletal $\delta^{18} \mathrm{O}$ and $\delta^{13} \mathrm{C}$ record of four female and six male Porites panamensis coral collected in Bahía de La Paz, Mexico, whose growth bands spanned 12 years. The isotopic data were compared to SST, precipitation, photosynthetically active radiation (PAR), chlorophyll $a$, and skeletal growth parameters. Porites panamensis is a known gonochoric brooder whose growth parameters are different in females and males. Splitting the data by sexes explained 81 and $93 \%$ of the differences of $\delta^{18} \mathrm{O}$, and of $\delta^{13} \mathrm{C}$, respectively, in the isotope record between colonies. Both isotope records were different between sexes. $\delta^{18} \mathrm{O}$ was higher in female colonies than in male colonies, with a $0.31 \%$ difference; $\delta^{13} \mathrm{C}$ was lower in female colonies, with a $0.28 \%$ difference. A difference in the skeletal $\delta^{18} \mathrm{O}$ could introduce an error in SST estimates of $\approx 1.0$ to $\approx 2.6^{\circ} \mathrm{C}$. The $\delta^{18} \mathrm{O}$ records showed a seasonal pattern that corresponded to SST,
\end{abstract}

with low correlation coefficients $(-0.45,-0.32)$, and gentle slopes $\left(0.09,0.10 \% 0^{\circ} \mathrm{C}^{-1}\right)$ of the $\delta^{18} \mathrm{O}-\mathrm{SST}$ relation. Seasonal variation in coral $\delta^{18} \mathrm{O}$ represents only 52.37 and $35.66 \%$ of the SST cycle; 29.72 and $38.53 \%$ can be attributed to $\delta^{18} \mathrm{O}$ variability in seawater. $\delta^{13} \mathrm{C}$ data did not correlate with any of the environmental variables; therefore, variations in skeletal $\delta^{13} \mathrm{C}$ appear to be driven mainly by metabolic effects. Our results support the hypothesis of a sex-associated difference in skeletal $\delta^{18} \mathrm{O}$ and $\delta^{13} \mathrm{C}$ signal, and suggest that environmental conditions and coral growth parameters affect skeletal isotopic signals differently in each sex. Although these findings relate to one gonochoric brooding species, they may have some implications for the more commonly used gonochoric spawning species such as Porites lutea and Porites lobata.

\section{Introduction}

Massive hermatypic coral are useful as recorders of oceanic conditions because their growth and skeletal materials incorporated during growth are affected by environmental variables. The calcareous material is deposited in annual density bands that allow for the determination of events over time (Druffel, 1997; Gagan et al., 2000; Grottoli and Eakin, 2007; Lough and Barnes, 2000; Lough and Cooper, 2011). This memory of oceanographic conditions at the time of calcifica- 
tion records variations at the intra-annual, inter-annual, interdecadal, and sometimes centennial timescale of El NiñoSouthern Oscillation (ENSO), the Pacific Decadal Oscillation (PDO), and pre- and post-industrial climate variability and change (Grottoli and Eakin, 2007). Skeletal growth, isotope composition, and minor and trace element ratios in coral skeletons vary in a predictable way with environmental variations in temperature, salinity, precipitation, cloud cover, fresh water discharge, upwelling, and $\mathrm{pH}$ (Dunbar and Wellington, 1981; Bernal and Carriquiry, 2001; Hönisch et al., 2004; Grottoli and Eakin, 2007). Among the proxies used in coral skeletons (trace element ratios, $\delta^{18} \mathrm{O}, \delta^{13} \mathrm{C}, \delta^{11} \mathrm{~B}, \delta^{15} \mathrm{~N}$ ), skeletal $\delta^{18} \mathrm{O}$ and $\delta^{13} \mathrm{C}$ are the most common measurements because they are relatively easy to measure (Dunbar et al., 1994; Linsley et al., 1994; Swart et al., 1996a; Tudhope et al., 1996; Charles et al., 1997; Schrag, 1999).

Most of the variability in skeletal $\delta^{18} \mathrm{O}$ in calcifying organisms, including coral, results from a combination of temperature-induced isotopic fractionation of local seawater $\delta^{18} \mathrm{O}\left(\delta^{18} \mathrm{O}_{\mathrm{sw}}\right)$ that depends on changes in precipitation and oceanic evaporation, which affect salinity (Epstein et al., 1953). Depletion in carbonate $\delta^{18} \mathrm{O}$ occurs as temperature increases in inorganic and biogenic carbonates (Allison et al., 1996). In tropical and subtropical oceans, variations in salinity caused by evaporation, rainfall, or river run-off affect skeletal $\delta^{18} \mathrm{O}$ and need to be considered when establishing a skeletal $\delta^{18}$ O-SST relationship (Cole and Fairbanks, 1990; Carriquiry et al., 1994; Al-Rousan et al., 2007; Sazzad et al., 2010).

Variations of skeletal $\delta^{13} \mathrm{C}$ are controlled mainly by an interrelationship between photosynthesis, respiration, and feeding. During high photosynthesis, zooxanthellae fixation of ${ }^{12} \mathrm{CO}_{2}$ increases, which leads to an increase in ${ }^{13} \mathrm{CO}_{2}$ in the coral carbon pool. Hence, coral skeletons formed during periods of high photosynthesis contain greater amounts of ${ }^{13} \mathrm{C}$ (Swart, 1983; McConnaughey, 1989; McConnaughey et al., 1997). During seasons with lower photosynthetic activity or when the photosynthesis to respiration ratio falls, coral skeletons would have lesser amounts of ${ }^{12} \mathrm{C}$. Changes in the photosynthesis-respiration ratio are influenced by photoperiods, photo-intensity, and temperature; where longer photoperiods and higher temperatures promote higher photosynthesis-respiration ratios (higher ${ }^{13} \mathrm{C}$ ). If maximum solar radiation occurs during summer, skeletal $\delta^{13} \mathrm{C}$ will be inversely related to $\delta^{18} \mathrm{O}$; if the maximum photoperiod occurs during colder seasons, $\delta^{13} \mathrm{C}$ and $\delta^{18} \mathrm{O}$ will be positively related (Swart et al., 1996b). Since zooplankton have generally low isotope levels, compared to coral skeletons and zooxanthellae, an increase in the heterotrophic activity of coral should reduce the $\delta^{13} \mathrm{C}$ of coral skeletons (Grottoli and Wellington, 1999). Felis et al. (1998) and Bernal and Carriquiry (2001) demonstrated that levels of coral skeletal $\delta^{13} \mathrm{C}$ decrease during upwelling events that bring nutrients to surface waters, with high concentrations of zooplankton related to decreasing zooxanthellae photosyn- thetic activity, and an increase in coral heterotrophic feeding (Cole et al., 1993; Quinn et al., 1993).

The $\delta^{18} \mathrm{O}$ and $\delta^{13} \mathrm{C}$ in coral skeletons are depleted in ${ }^{18} \mathrm{O}$ and ${ }^{13} \mathrm{C}$, in comparison to inorganic aragonite precipitated under isotope equilibrium (Weber and Woodhead, 1972; McConnaughey, 1989). This departure from equilibrium is referred to as "the vital effect" and appears to be constant along the coral growth axis (Land et al., 1975; McConnaughey, 1989; Barnes and Lough, 1992; Barnes et al., 1995; Wellington et al., 1996). Isotope disequilibrium of coral skeletons results from coral precipitating their skeletons too quickly to attain isotope equilibrium (McConnaughey, 1989). Hence, all coral skeletons contain appreciable amounts of carbon and oxygen, which have not been allowed to equilibrate with the ambient conditions and are isotopically depleted.

Variations in coral skeletal growth parameters (skeletal density, extension, and calcification rate) are possible sources of deviation from oxygen and carbon isotope fractionation, which affect the external controls of the isotopes (Allison et al., 1996; Lough et al., 1996; Barnes et al., 1995; Cohen and Hart, 1997). Skeletal growth parameters in coral have sexbased differences in some gonochoric species (Cabral-Tena et al., 2013; Carricart-Ganivet et al., 2013), so it is possible for the sex of a coral colony to be another cause of deviation in oxygen and carbon isotope fractionation. The influence of metabolic effects, such as reproduction, is another factor affecting the $\delta^{18} \mathrm{O}$ and $\delta^{13} \mathrm{C}$ signal in skeletons (Kramer et al., 1993; Gagan et al,. 1994; Barnes et al., 1995; Taylor et al., 1995; Allison et al., 1996; Cohen and Hart, 1997; Lough et al., 1996; Swart et al., 1996b).

The stony coral Porites panamensis has a wide distribution along the eastern tropical Pacific, from Mexico to Ecuador, and tolerates a wide range of environmental conditions, including low temperature and high-turbidity that are often stressful to other coral species (Halfar et al., 2005; ReyesBonilla et al., 2007). This coral has extension rates ranging from 0.4 to $1.2 \mathrm{~cm} \mathrm{yr}^{-1}$, along the coast of Mexico and Costa Rica (Guzmán and Cortés, 1989; Halfar et al., 2005; CabralTena et al., 2013), where extension and calcification rates are different in males and females (Cabral-Tena et al., 2013). $P$. panamensis is a gonochoric brooder with reproductive activity throughout the year (Glynn et al., 1994; Carpizo-Ituarte et al., 2011; Rodríguez-Troncoso et al., 2011).

This study describes changes in the skeletal isotopic oxygen and carbon record of six male and four female P. panamensis coral, collected in Bahía de La Paz, with growth density banding covering 12 years. Oxygen and carbon isotope measurements were used to assess a possible sex-associated variation in the coral skeletal $\delta^{18} \mathrm{O}$ and $\delta^{13} \mathrm{C}$ signal related to differences in the "vital effect" of colonies between sexes. The isotopic record was compared to surface seawater temperature (SST), rainfall, photosynthetically active radiation (PAR), concentration of chlorophyll $a$, and skeletal growth data. 


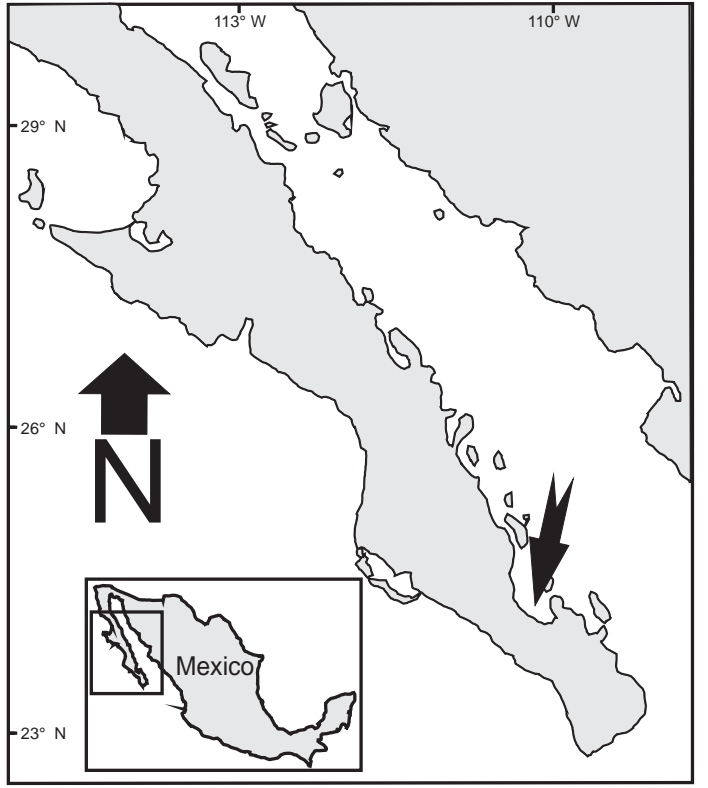

Figure 1. Map showing location of coral sampling site in Bahía de La Paz, México.

\section{Materials and methods}

\subsection{Collection and identification of sex}

Ten colonies of Porites panamensis were collected in Bahía de La Paz (Fig. $1 ; 24^{\circ} \mathrm{N}, 110^{\circ} \mathrm{W}$ ) during the main reproductive period (March) of this genus (Glynn et al., 1994; Carpizo-Ituarte et al., 2011; Rodriguez-Troncoso et al., 2011). The specimens were collected in 2011 at depths of $3-$ $4 \mathrm{~m}$. Divers used a hammer and chisel to remove the colonies from the substrate. A fragment from each colony was fixed in Davison's solution for a histological examination and identification of sex (Howard and Smith, 1983). These are the same 10 colonies presented in the Cabral-Tena et al. (2013) study.

Coral fragments were first decalcified for $24 \mathrm{~h}$ in a solution containing $10 \% \mathrm{HCl}, 0.7 \mathrm{~g}$ EDTA, $0.008 \mathrm{~g}$ sodium potassium tartrate, and $0.14 \mathrm{~g}$ sodium tartrate in 1 liter of distilled water (Glynn et al., 1994). The tissue was then rinsed under running water until free of acid, and placed in $70 \%$ ethanol until processed by conventional histological techniques (Humason, 1979). Transverse $8 \mu \mathrm{m}$ sections were prepared with a rotator manual microtome, and stained with hematoxylin and eosin. After staining, the samples were studied under a compound microscope. The colonies were identified as female if any planulae or oocytes were observed, regardless of their stage of development; the colonies were identified as male if any spermatocytes were observed in the slide section.

\subsection{Growth parameters}

From each colony, three slices (7-8 $\mathrm{mm}$ thick) were cut along the major growth axis. Slices were air-dried and X-rayed with a digital mammograph machine (Senographe 600T, GE Healthcare, Little Chafont, UK). Images were made at $36 \mathrm{kVp}$ for $980 \mathrm{mAs}$ and $30 \mathrm{~cm}$ source-to-subject distance. $\mathrm{X}$-ray films were digitized with a Kodak DirectView Classic CR System, at 75 dpi resolution. An aragonite step-wedge was included on each X-radiograph as a reference for calculating skeletal density. The step-wedge was built from eight blocks cut from a shell of Tridacna maxima; each block had an area of $2.5 \mathrm{~cm}^{2}$ and varied in thickness from 0.09 to $1.18 \mathrm{~cm}$. Optical density tracks were located on the maximum growth axis in the digital X-radiography of each slice; density was measured using the ImageJ 1.44 image processing program (http://imagej.nih.gov/ij). A data series of absolute density versus distance was generated and dated backwards for each slice, using photodensitometry (CarricartGanivet and Barnes, 2007). The coral year starts in the summer, with the highest SST at the sampling site (Hudson et al., 1976). The maximum and minimum density for each year (1993 through 2009) were identified in each density series.

\subsection{Isotope analysis}

After the skeletal growth analysis, one slice covering the most extensive chronological extension of each of the 10 colonies was selected for isotope analysis. Continuous samples of aragonite powder were collected along each coral's maximum growth axis using a drill with a $0.1 \mathrm{~mm}$ bit. Each sample was $\sim 1 \mathrm{~mm}$ apart. The milling process was done by hand milling.

Aragonite powder was analyzed using an isotope ratio mass spectrometer (Delta V Plus, Thermo Scientific, Waltham, MA) with an automated system for carbon analysis in an acid bath (Finnigan Gas Bench II, Thermo Electron, Madison, WI). Each isotope sample had $<0.05 \%$ orror. Reference NBS-19 (International Atomic Energy Agency, Vienna, Austria) was used as the isotope standard. The seasonal pattern of $\delta^{18} \mathrm{O}$ was used to establish chronology. This is supported by the consistent pattern of annual density-band pairs described for Porites by Lough and Barnes (2000). Chronologies were established by designating the minimum $\delta^{18} \mathrm{O}$ value in a year to summer (consistent with maximum SST). To eliminate the effects of different sampling resolutions on the calculation of mean coral $\delta^{18} \mathrm{O}$ values due to differences in linear extension rates of each colony, the results were interpolated to create four equally spaced values per year.

The Heikoop et al. (2000) correction factor was applied to isolate the kinetic and metabolic effects in the $\delta^{13} \mathrm{C}$ of male and female colonies. We chose Heikoop et al. (2000) correction factor over Omata et al. (2008) because the temperature of skeleton precipitation was not the same during the entire study. 


\subsection{Environmental data}

Monthly SST, PAR, and concentration of chlorophyll $a$ data were obtained from the NOAA live access server (http://las. pfeg.noaa.gov/oceanWatch/oceanwatch.php; Simons, 2015). The environmental data spanned from 1997-2009, and in situ thermograph temperature data (2003-2007) from the Marine Observatory for the Mexican Pacific region (Sicard-González et al., 2012). This information was used to compare satellite and in situ temperature data covering from 2003 to 2007. Both temperature records (satellite and in situ measurements) from Bahía de La Paz showed the same seasonal signal and a close fit $(r=0.90, p<0.05)$. This result supports the use of satellite SST data for coral skeletal $\delta^{18} \mathrm{O}$ calibration. Monthly rainfall data (1997-2009) were obtained from the Servicio Meteorológico Nacional (http://smn.cna.gob.mx/; CLICOM, 2015). Some sea surface salinity data were obtained from previous published data in the study area (ObesoNiebla, 2007). $\delta^{18} \mathrm{O}_{\text {sw }}$ was calculated from the $\delta^{18} \mathrm{O}$ relationship with the salinity equation for the Eastern Pacific (Fairbanks et al., 1997).

\subsection{Statistical analyses}

Normality and homoscedasticity of the data were tested using Kolmogorov-Smirnov and Bartlett tests, respectively. Student's $t$ test for independent samples with uneven variance was used to assess statistical differences in $\delta^{18} \mathrm{O}$ and $\delta^{13} \mathrm{C}$ between sexes and to compare both sets of means obtained using the Heikoop et al. (2000) correction factor (kinetic and metabolic $\delta^{13} \mathrm{C}$ ). Pearson's correlation test and simple linear regressions were used to estimate relationships between mean skeletal extension rate, skeletal density, and calcification rate with isotope data of both sexes. An ANCOVA test was used to assess the differences between slopes and the $y$ intercept of linear equations of $\delta^{13} \mathrm{C}$ versus $\delta^{18} \mathrm{O}$ plots of the results of male and female data.

Pearson's correlation test and simple linear regressions were used to estimate relationships between environmental data and isotope data of both sexes. A Regime shift index for environmental and isotope data was calculated with the Sequential Regime Shift Detection Software (Rodionov, 2004).

\section{Results}

\subsection{Skeletal growth}

All specimens were collected in March, a period of seasonally low SST in Bahía de La Paz. All X-radiographs had a low-density annual growth band in the apex of the slice. This means that $P$. panamensis form a low-density band in winter. Annual growth bands in each colony were dated and the sampling resolution for isotope analysis was determined.

The average yearly extension rate was $1.05 \pm 0.04$ for female colonies, and $1.27 \pm 0.04$ for male colonies. The

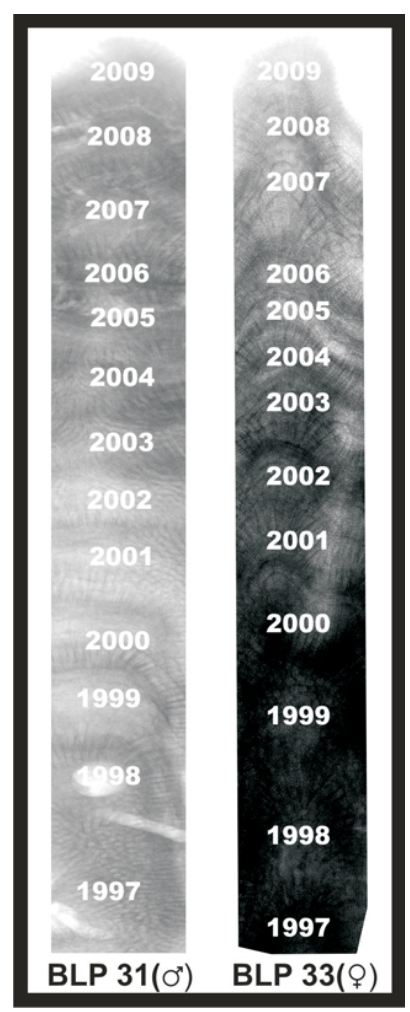

Figure 2. Positive X-Radiographs showing skeletal growth density band pairs of two Porites panamensis corals (one male and one female) of Bahía de La Paz. The numbers on the image mark the years of the corresponding high-density bands.

average skeletal density was $0.94 \pm 0.01$ for females, and $0.95 \pm 0.01 \mathrm{~g} \mathrm{~cm}^{-3}$ for males. The average calcification rate was $0.97 \pm 0.04$ for females, and $1.24 \pm 0.03 \mathrm{~g} \mathrm{~cm}^{-2} \mathrm{yr}^{-1}$ for males. Figure 2 shows X-ray positive prints for two of the samples.

\subsection{Skeletal isotope composition and environmental data}

The $\delta^{18} \mathrm{O}$ quarterly records of female and male coral colonies show a seasonal pattern (Fig. 3) that was significantly correlated between sexes $(r=0.45, p>0.000001)$, thus both sexes showed the same seasonal pattern. $\delta^{18} \mathrm{O}$ in female colonies, was higher than in male colonies (Fig. 3). The overall average $\delta^{18} \mathrm{O}$ in female colonies was $-2.89 \pm 0.33$ and $-3.20 \pm 0.37 \%$ in male colonies (Table 1). Overall, the $\delta^{18} \mathrm{O}$ average of females is significantly higher than that of males $\left(t_{498}=9.34, p>0.00001\right)$. Quarterly $\delta^{18} \mathrm{O}$ time series of all colonies showed a "regime shift" of the mean in 2004, from -2.75 to $-3.14 \%$, with a regime shift index (RSI) of $-0.69(p=0.008)$ in female colonies, and from -3.08 to $-2.42 \%$ with an RSI of $-0.65(p=0.003)$ in male colonies. This coincides with a regime shift in the rainfall mean of 

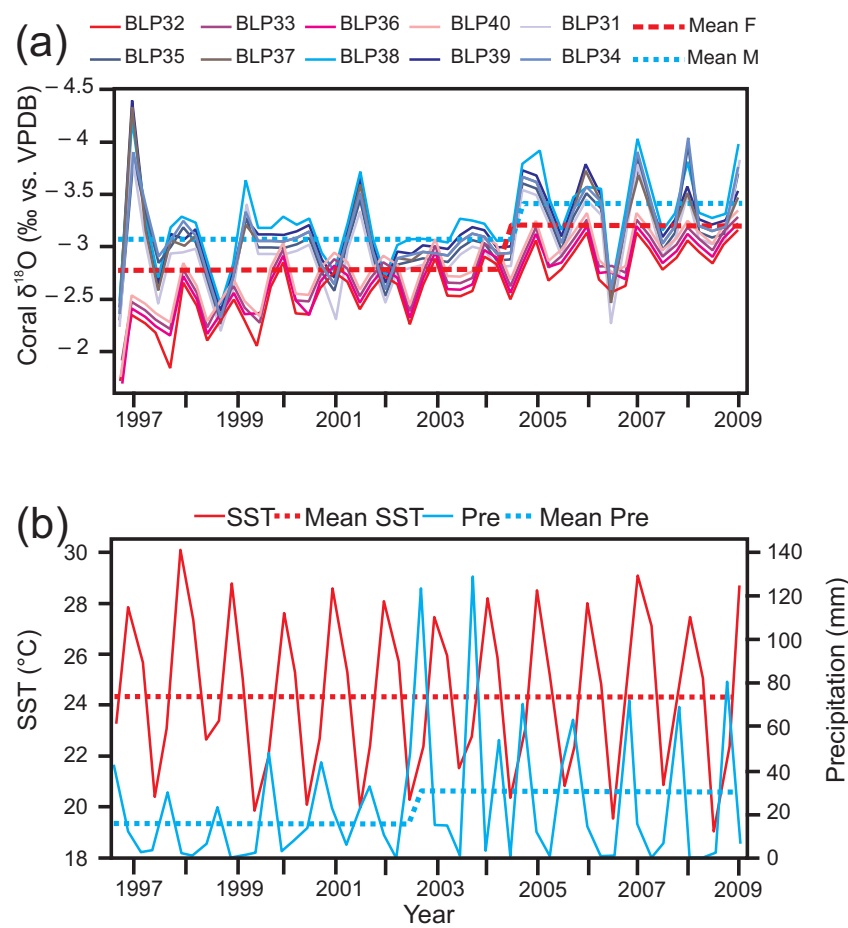

Figure 3. (a) Seasonal variation in $\delta^{18} \mathrm{O}$ composition (VPDB) from Porites panamensis coral colonies along the major growth axis. Blue lines represent male colonies; red lines represent female colonies; red dotted line female colonies' regime mean; blue dotted line, male colonies' regime mean. (b) Satellite sea surface temperature and precipitation (1997-2009) records. Sea surface temperature (red line; ${ }^{\circ} \mathrm{C}$ ), mean sea surface temperature (dotted red line; ${ }^{\circ} \mathrm{C}$ ), precipitation (blue line; $\mathrm{mm}$ ), mean precipitation (dotted blue line; $\mathrm{mm}$ ). Note the regime shift in the precipitation mean in 2003.

2003, changing from 15.76 to $30.25 \mathrm{~mm}$, with an RSI of 0.30 $(p=0.01)$, as seen in Fig. 3b.

The quarterly $\delta^{13} \mathrm{C}$ time series showed a cyclic pattern in female and male colonies (Fig. 4), that was correlated between both sexes $(r=0.19, p=0.005)$, thus both sexes showed the same seasonal pattern. The skeletal $\delta^{13} \mathrm{C}$ of female colonies was lower than the skeletal $\delta^{13} \mathrm{C}$ of male colonies (Fig. 4). The overall average of $\delta^{13} \mathrm{C}$ in female colonies was $-1.66 \pm 0.38$ and $-1.38 \pm 0.37 \%$ in male colonies (Table 1). The overall average of $\delta^{13} \mathrm{C}$ in females is significantly lower than in males $\left(t_{498}=-8.01\right.$, $p>0.00001)$. No regime shift was found in the $\delta^{13} \mathrm{C}$ data of either sex.

The $\delta^{18} \mathrm{O}$ skeletal data series corresponds to the SST (Fig. 3). Table 2 shows correlation coefficients between the $\delta^{18} \mathrm{O}$ isotope data of coral colonies and environmental variables. The correlation coefficient between the isotope average time series data and SST was $-0.45(p=0.00003)$ for female colonies, and $-0.32(p=0.0005)$ for male colonies; the $r$-to- $z$ transformation showed that both correlation coefficients are equally significant $(z=-1469 ; p=0.07)$. No
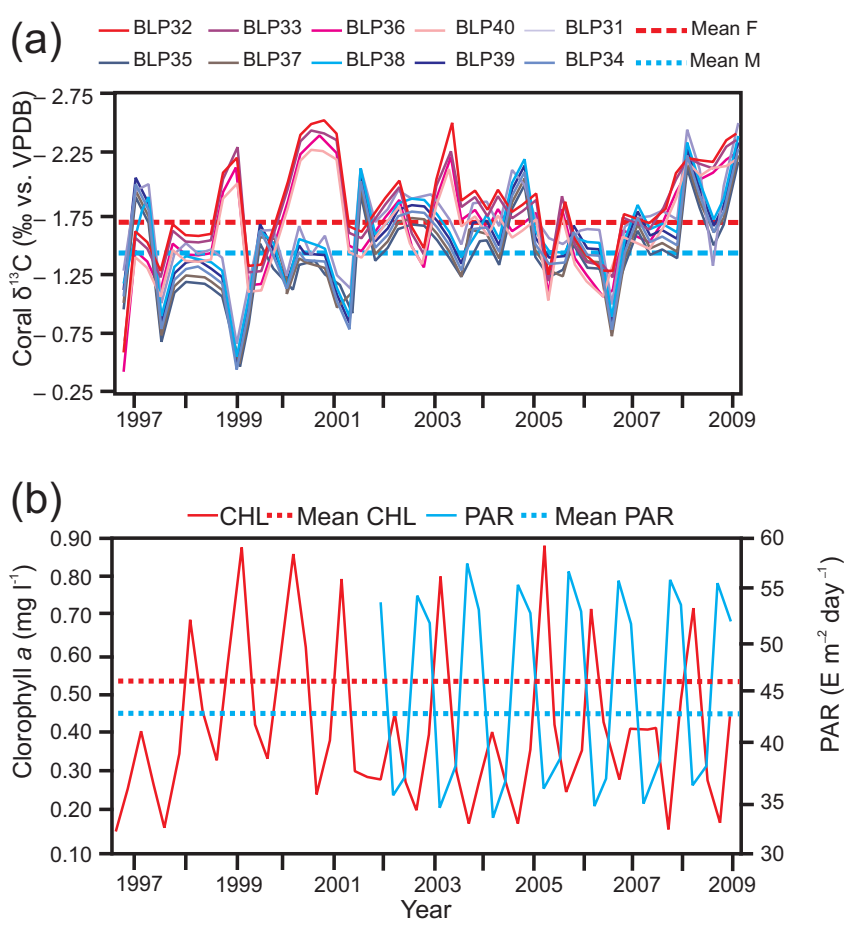

Figure 4. (a) Seasonal variation in $\delta^{13} \mathrm{C}$ composition (VPDB) from Porites panamensis coral colonies along the major growth axis. Blue lines represent male colonies; red lines represent female colonies; red dotted line female colonies' regime mean; blue dotted line, male colonies' regime mean. (b) Satellite chlorophyll $a$ and PAR (1997-2009) records. Clorophyll $a$ (red line; $\mathrm{mg} \mathrm{L}^{-1}$ ), mean chlorophyll $a$ (dotted red line; $\mathrm{mg} \mathrm{L}^{-1}$ ), photosynthetically active radiation (blue line; $\mathrm{E} \mathrm{m}^{-2} \mathrm{~d}^{-1}$ ), photosynthetically active radiation (dotted blue line; $\mathrm{E} \mathrm{m}^{-2} \mathrm{~d}^{-1}$ ).

significant correlation was found between the $\delta^{18} \mathrm{O}$ skeletal data sets and the rainfall data. The $\delta^{13} \mathrm{C}$ skeletal data series did not significantly correlate with any of the environmental variables in any of the colonies (Table 3). The temporal resolution of compared data (isotopes vs. environmental data) is quarterly in all cases.

Heikoop et al. (2000) correction factor results are shown in Table 4. The overall average of $\delta^{13} \mathrm{C}$ in female colonies was $-1.66 \pm 0.38$ and $-1.38 \pm 0.37 \%$ in male colonies. Student's $t$ test showed that both sets of means (kinetic and metabolic) are significantly different between male and female colonies $\left(t_{498}=13.074, p<0.000001\right.$ for Kinetic means; $t_{498}=-13.98, p<0.000001$ Metabolic means).

\subsection{Skeletal isotopic composition and skeletal growth}

The analysis showed that high density bands are depleted in ${ }^{18} \mathrm{O}$ and ${ }^{13} \mathrm{C}$, which are deposited during summer; low density bands are enriched in ${ }^{18} \mathrm{O}$ and ${ }^{13} \mathrm{C}$, which are deposited during winter. In female colonies, a significant negative correlation between the mean annual coral $\delta^{18} \mathrm{O}$ and annual skeletal density was found (Table 5; $r=-0.78, p=$ 
Table 1. Summary of the overall average extension rate, skeletal density, calcification rate, $\delta^{18} \mathrm{O}$ and $\delta^{13} \mathrm{C}$ of Porites panamensis colonies from Bahía de La Paz, Gulf of California. Time period of data is from 1997 to 2009.

\begin{tabular}{lllllll}
\hline Colony & Sex & $\begin{array}{l}\text { Avg Ext } \\
\left(\mathrm{cm} \mathrm{yr}^{-1}\right)\end{array}$ & $\begin{array}{l}\text { Avg Den } \\
\left(\mathrm{g} \mathrm{cm}^{-3}\right)\end{array}$ & $\begin{array}{l}\text { Avg Cal } \\
\left(\mathrm{g} \mathrm{cm}^{-2} \mathrm{yr}^{-1}\right)\end{array}$ & $\begin{array}{l}\mathrm{Avg} \delta^{18} \mathrm{O} \\
(\%)\end{array}$ & $\begin{array}{l}\mathrm{Avg} \delta^{13} \mathrm{C} \\
(\%)\end{array}$ \\
\hline BLP32 & $\mathrm{F}$ & $1.06 \pm 0.32$ & $0.87 \pm 0.04$ & $0.88 \pm 0.25$ & $-2.94 \pm 0.35$ & $-1.66 \pm 0.38$ \\
BLP33 & $\mathrm{F}$ & $0.94 \pm 0.22$ & $0.98 \pm 0.01$ & $0.93 \pm 0.22$ & $-2.88 \pm 0.32$ & $-1.65 \pm 0.39$ \\
BLP36 & $\mathrm{F}$ & $1.05 \pm 0.31$ & $0.93 \pm 0.04$ & $1.03 \pm 0.29$ & $-2.89 \pm 0.33$ & $-1.67 \pm 0.38$ \\
BLP40 & $\mathrm{F}$ & $1.10 \pm 0.19$ & $0.94 \pm 0.02$ & $1.03 \pm 0.17$ & $-2.87 \pm 0.31$ & $-1.66 \pm 0.39$ \\
BLP31 & $\mathrm{M}$ & $1.21 \pm 0.61$ & $0.90 \pm 0.08$ & $1.21 \pm 0.44$ & $-3.19 \pm 0.38$ & $-1.39 \pm 0.37$ \\
BLP34 & $\mathrm{M}$ & $1.35 \pm 0.30$ & $0.98 \pm 0.04$ & $1.33 \pm 0.29$ & $-3.25 \pm 0.38$ & $-1.37 \pm 0.37$ \\
BLP35 & $\mathrm{M}$ & $1.59 \pm 0.31$ & $0.95 \pm 0.01$ & $1.61 \pm 0.28$ & $-3.19 \pm 0.37$ & $-1.39 \pm 0.37$ \\
BLP37 & $\mathrm{M}$ & $1.28 \pm 0.34$ & $0.96 \pm 0.03$ & $1.23 \pm 0.34$ & $-3.21 \pm 0.39$ & $-1.39 \pm 0.38$ \\
BLP38 & $\mathrm{M}$ & $0.83 \pm 0.36$ & $0.88 \pm 0.02$ & $0.75 \pm 0.33$ & $-3.19 \pm 0.37$ & $-1.39 \pm 0.38$ \\
BLP39 & $\mathrm{M}$ & $1.39 \pm 0.40$ & $1.00 \pm 0.02$ & $1.40 \pm 0.40$ & $-3.18 \pm 0.37$ & $-1.38 \pm 0.37$ \\
Avg F & $\mathrm{F}$ & $1.05 \pm 0.04$ & $0.94 \pm 0.01$ & $0.97 \pm 0.04$ & $-2.89 \pm 0.33$ & $-1.66 \pm 0.38$ \\
Avg M & $\mathrm{M}$ & $1.27 \pm 0.04$ & $0.95 \pm 0.01$ & $1.24 \pm 0.03$ & $-3.20 \pm 0.37$ & $-1.38 \pm 0.37$ \\
\hline
\end{tabular}

Table 2. Correlation coefficients between skeletal $\delta^{18} \mathrm{O}$ of Porites panamensis colonies and: sea surface temperature, precipitation, photosynthetically active radiation and chlorophyll $a$ from Bahía de La Paz. Time period covered by correlations is from 1997 to 2009 . Temporal resolution of data is quarterly. Bold numbers indicate significant $(p<0.05)$ correlations.

\begin{tabular}{|c|c|c|c|c|c|c|c|c|c|}
\hline \multirow[t]{2}{*}{ Colony } & \multirow[t]{2}{*}{ Sex } & \multicolumn{2}{|c|}{ SST } & \multicolumn{2}{|c|}{ Precipitation } & \multicolumn{2}{|c|}{ PAR } & \multicolumn{2}{|c|}{ Chlorophyll $a$} \\
\hline & & $r$ & $p$ & $r$ & $p$ & $r$ & $p$ & $r$ & $p$ \\
\hline BLP32 & $\mathrm{F}$ & -0.36 & 0.007 & 0.10 & 0.44 & -0.41 & 0.02 & -0.08 & 0.55 \\
\hline BLP33 & $\mathrm{F}$ & -0.35 & 0.01 & 0.07 & 0.58 & -0.40 & 0.03 & -0.11 & 0.44 \\
\hline BLP36 & $\mathrm{F}$ & -0.37 & 0.006 & 0.08 & 0.55 & -0.42 & 0.02 & -0.11 & 0.42 \\
\hline BLP40 & $\mathrm{F}$ & -0.38 & 0.006 & 0.08 & 0.54 & -0.41 & 0.02 & -0.11 & 0.43 \\
\hline BLP31 & M & -0.28 & 0.04 & 0.05 & 0.68 & -0.36 & 0.05 & -0.06 & 0.64 \\
\hline BLP34 & M & -0.26 & 0.06 & 0.06 & 0.65 & -0.31 & 0.09 & -0.08 & 0.53 \\
\hline BLP35 & M & -0.29 & 0.03 & 0.06 & 0.67 & -0.36 & 0.05 & -0.06 & 0.65 \\
\hline BLP37 & M & -0.28 & 0.04 & 0.06 & 0.65 & -0.34 & 0.06 & -0.07 & 0.60 \\
\hline BLP38 & M & -0.29 & 0.03 & 0.06 & 0.67 & -0.36 & 0.04 & -0.05 & 0.68 \\
\hline BLP39 & M & -0.28 & 0.04 & 0.05 & 0.69 & -0.36 & 0.05 & -0.06 & 0.64 \\
\hline
\end{tabular}

0.001). This suggests that denser skeletons are more depleted in $\delta^{18} \mathrm{O}$, compared to less dense skeletons, and no significant correlation was found between $\delta^{18} \mathrm{O}$ and other skeletal growth parameters in female colonies; no significant correlations between mean annual coral $\delta^{13} \mathrm{C}$ and any growth parameters were found. In male colonies, there was a significant negative correlation between mean annual coral $\delta^{18} \mathrm{O}$ and the annual linear extension and calcification rates (Table $5 ; r=-0.50$ and $-0.44, p=0.045$ and 0.0008). This suggests that faster growing and calcifying colonies are more depleted in $\delta^{18} \mathrm{O}$. No significant correlation was found between $\delta^{18} \mathrm{O}$ and skeletal density in male colonies; no significant correlation between any coral growth parameter and mean annual coral $\delta^{13} \mathrm{C}$ was found.

\section{Discussion}

Our isotope data showed a significant dependency of skeletal $\delta^{18} \mathrm{O}$ on SST, with a low $r(-0.45$ in female coral, and -0.28 in male coral), and a gentle slope of the $\delta^{18} \mathrm{O}-\mathrm{SST}$ calibration equations $\left(0.09 \%{ }^{\circ} \mathrm{C}^{-1} \mathrm{~F}\right.$; $0.11 \% 0^{\circ} \mathrm{C}^{-1} \mathrm{M}$; Fig. 5), compared with slopes $\left(>0.20 \% 0^{\circ} \mathrm{C}^{-1}\right)$ in Porites spp. in other areas of the Pacific: the Great Barrier Reef (Gagan et al., 1994), Costa Rica (Carriquiry, 1994), Panama (Wellington and Dunbar, 1995), and the Galapagos Archipelago (McConnaughey, 1989). These studies show high correlation coefficients (better than -0.80) of $\delta^{18} \mathrm{O}$ and SST, all these studies have isotopic records between 5 to 40 years long, and with a high temporal resolution sampling (weekly to monthly). Our results are similar to studies reporting small correlation coefficients of $\delta^{18} \mathrm{O}$ and SST (less than -0.70) and a gentle slope $\left(<0.17 \% 0^{\circ} \mathrm{C}^{-1}\right)$ of the $\delta^{18} \mathrm{O}-\mathrm{SST}$ calibration equations, such as at Clipperton Atoll (Linsley et al., 1999), Fiji (Le Bec et al., 2000), and Guam (Asami et al., 2004), these 
Table 3. Correlation coefficients between skeletal $\delta^{13} \mathrm{C}$ of Porites panamensis colonies and: sea surface temperature, precipitation, photosynthetically active radiation and chlorophyll $a$ from Bahía de La Paz. Time period covered by correlations is from 1997 to 2009 . Temporal resolution of data is quarterly. Bold numbers indicate significant $(p<0.05)$ correlations.

\begin{tabular}{llrrrrrrrrr}
\hline Colony & Sex & \multicolumn{2}{c}{ SST } & \multicolumn{3}{c}{ Precipitation } & \multicolumn{2}{c}{ PAR } & \multicolumn{3}{c}{ Chlorophyll $a$} \\
& & $r$ & $p$ & $r$ & $p$ & $r$ & $p$ & $r$ & $p$ \\
\hline BLP32 & $\mathrm{F}$ & 0.19 & 0.17 & -0.07 & 0.62 & -0.11 & 0.54 & 0.10 & 0.45 \\
BLP33 & $\mathrm{F}$ & 0.17 & 0.22 & -0.04 & 0.73 & -0.12 & 0.51 & 0.11 & 0.43 \\
BLP36 & $\mathrm{F}$ & 0.17 & 0.22 & -0.06 & 0.63 & -0.16 & 0.38 & 0.09 & 0.51 \\
BLP40 & $\mathrm{F}$ & 0.15 & 0.28 & -0.07 & 0.62 & -0.11 & 0.54 & 0.08 & 0.52 \\
BLP31 & $\mathrm{M}$ & 0.005 & 0.97 & -0.01 & 0.89 & -0.33 & 0.07 & 0.24 & 0.08 \\
BLP34 & $\mathrm{M}$ & 0.03 & 0.79 & -0.02 & 0.86 & -0.35 & 0.05 & 0.25 & 0.07 \\
BLP35 & $\mathrm{M}$ & 0.01 & 0.93 & -0.02 & 0.84 & -0.35 & 0.06 & 0.26 & 0.05 \\
BLP37 & $\mathrm{M}$ & 0.01 & 0.92 & -0.01 & 0.93 & -0.32 & 0.08 & 0.25 & 0.07 \\
BLP38 & $\mathrm{M}$ & 0.003 & 0.98 & -0.01 & 0.93 & -0.32 & 0.09 & 0.25 & 0.07 \\
BLP39 & $\mathrm{M}$ & 0.02 & 0.88 & -0.02 & 0.88 & -0.33 & 0.07 & 0.24 & 0.09 \\
\hline
\end{tabular}

Table 4. Heikoop et al. (2000) correction factor results comparing transformed and metabolic skeletal $\delta^{13} \mathrm{C}$ of Porites panamensis colonies from Bahía de La Paz.

\begin{tabular}{lrrrr}
\hline & $\begin{array}{r}\text { Transformed } \\
\delta^{13} \mathrm{C} \text { Females } \\
(N=200)\end{array}$ & $\begin{array}{r}\text { Transformed } \\
\delta^{13} \mathrm{C} \text { Males } \\
(N=300)\end{array}$ & $\begin{array}{r}\text { Metabolic } \\
\delta^{13} \mathrm{C} \text { Females } \\
(N=200)\end{array}$ & $\begin{array}{r}\text { Metabolic } \\
\delta^{13} \mathrm{C} \text { Males } \\
(N=300)\end{array}$ \\
\hline Mean & 5.082 & 6.30 & 6.23 & 7.43 \\
$\mathrm{SD}$ & 0.90 & 0.97 & 0.90 & 0.96 \\
\hline
\end{tabular}

studies have long isotopic records (20 to 25 years) and a high temporal resolution sampling (daily to monthly) compared to our data (12 years of data with a quarterly sampling resolution).

Asami et al. (2004) suggest that the low correlation coefficient between $\delta^{18} \mathrm{O}$ and SST, and the gentle slope in the $\delta^{18} \mathrm{O}-\mathrm{SST}$ calibration equations are related to small seasonal variations in $\mathrm{SST}\left(<3^{\circ} \mathrm{C}\right)$, or the greater influence of $\delta^{18} \mathrm{O}_{\mathrm{sw}}$. The seasonal variation in SST of our study area is $7.85 \pm 0.77^{\circ} \mathrm{C}$, so the seasonal variation of SST is not likely to be the cause. Variations in $\delta^{18} \mathrm{O}_{\mathrm{sw}}$ represent $29.72 \%$ in female coral, and $38.53 \%$ in male coral, of the average seasonal $\delta^{18} \mathrm{O}$ variation. We found a significant regime shift in the $\delta^{18} \mathrm{O}$ data of colonies of both genders, that coincides with a regime shift in rainfall. This means that the $\delta^{18} \mathrm{O}$ of coral in Bahía de La Paz is influenced more by the $\delta^{18} \mathrm{O}_{\mathrm{sw}}$ than in other places in the Pacific.

The linear regression (Fig. 5) equations for $\delta^{18} \mathrm{O}$ dependence on SST (1997-2009) were SST $=7.0889-5.7193$ $\left(\delta^{18} \mathrm{O}\right),\left(r^{2}=0.23, p=0.00003\right)$ for female coral, and $\mathrm{SST}=14.739-2.9246\left(\delta^{18} \mathrm{O}\right)\left(r^{2}=0.10, p=0.00007\right)$ for male coral.

The annual range of $\delta^{18} \mathrm{O}$ was the difference between the highest $\delta^{18} \mathrm{O}$ measurement in January-March, and the lowest in July-September (1997-2008). The average amplitude was $0.37 \pm 0.15 \%$ in female colonies, and $0.28 \pm 0.72 \%$ in male
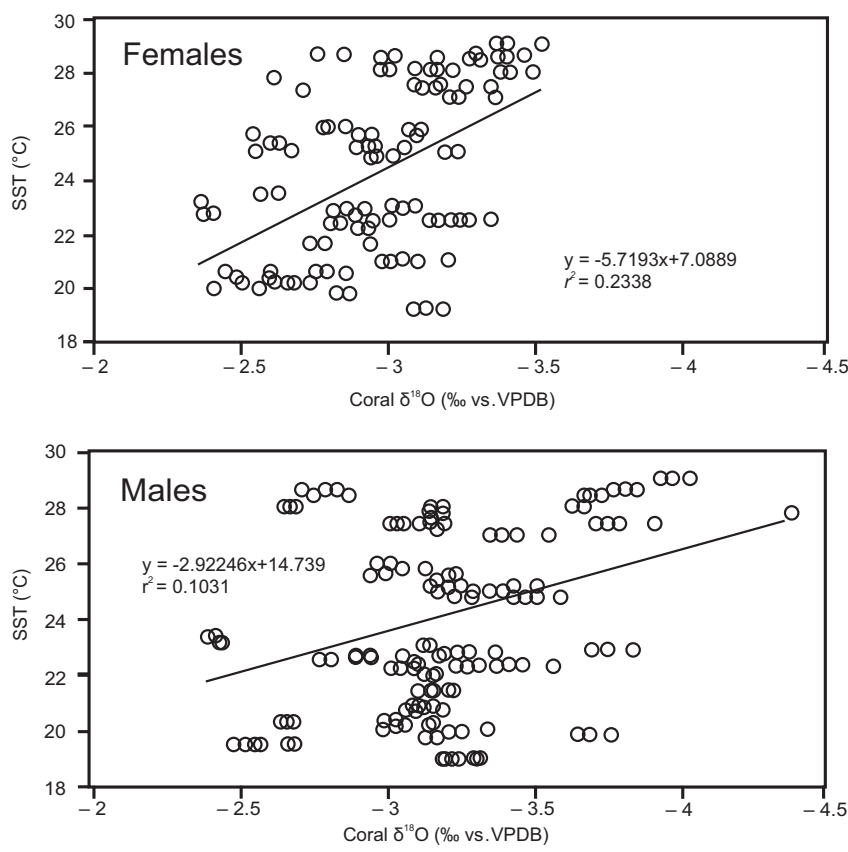

Figure 5. Linear regressions between satellite-derived sea surface temperature $\left({ }^{\circ} \mathrm{C}\right)$ and skeletal $\delta^{18} \mathrm{O}(\mathrm{VPDB})$ of female, and male Porites panamensis coral from Bahía de La Paz. Time period covered by analyses is from 1997 to 2009 . Temporal resolution of data is quarterly. This includes all isotopic data of all colonies. Line equations and coefficients are shown.

colonies. Satellite SST data had an average amplitude cycle of $7.85 \pm 0.77^{\circ} \mathrm{C}$, and rainfall had an average annual amplitude of $3.55 \pm 16.07 \mathrm{~mm}$. Using the calculated gradients of $0.09 \%{ }^{\circ} \mathrm{C}^{-1}$ for female colonies, and $0.10 \% 0^{\circ} \mathrm{C}^{-1}$ for male colonies, the average seasonal variation of $\delta^{18} \mathrm{O}$ would reflect a temperature change of $4.11^{\circ} \mathrm{C}$ in female colonies, and $2.80{ }^{\circ} \mathrm{C}$ in male colonies. This is $52.37 \%$ in female colonies, and $35.66 \%$ in male colonies of the seasonal range 
Table 5. Correlation coefficients between skeletal extension rate, skeletal density and calcification rate, and skeletal $\delta^{18} \mathrm{O}$ and $\delta^{13} \mathrm{C}$ of Porites panamensis colonies from Bahía de La Paz. Time period covered by correlations is from 1997 to 2009. Temporal resolution of data is annual. Bold numbers indicate significant $(p<0.05)$ correlations.

\begin{tabular}{lcrrrrrrrrrrrrr}
\hline Colony & Sex & \multicolumn{2}{c}{ Ext vs. $\delta^{18} \mathrm{O}$} & \multicolumn{2}{c}{ Den vs. $\delta^{18} \mathrm{O}$} & \multicolumn{2}{c}{ Cal vs. $\delta^{18} \mathrm{O}$} & \multicolumn{3}{c}{ Ext vs. $\delta^{13} \mathrm{C}$} & \multicolumn{3}{c}{ Den vs. $\delta^{13} \mathrm{C}$} & \multicolumn{3}{c}{ Cal vs. $\delta^{13} \mathrm{C}$} \\
& & $r$ & $p$ & $r$ & $p$ & $r$ & $p$ & $r$ & $p$ & $r$ & $p$ & $r$ & $p$ \\
\hline BLP32 & $\mathrm{F}$ & 0.34 & 0.24 & $\mathbf{- 0 . 8 1}$ & $\mathbf{0 . 0 0 1}$ & 0.31 & 0.23 & 0.42 & 0.14 & -0.20 & 0.53 & 0.43 & 0.14 \\
$\mathrm{BLP33}$ & $\mathrm{F}$ & 0.37 & 0.22 & $\mathbf{- 0 . 8 5}$ & $\mathbf{0 . 0 0 1}$ & 0.40 & 0.19 & 0.45 & 0.12 & -0.11 & 0.71 & 0.39 & 0.23 \\
$\mathrm{BLP36}$ & $\mathrm{F}$ & 0.34 & 0.21 & $\mathbf{- 0 . 7 8}$ & $\mathbf{0 . 0 0 3}$ & 0.41 & 0.17 & 0.41 & 0.11 & -0.07 & 0.80 & 0.45 & 0.13 \\
$\mathrm{BLP} 40$ & $\mathrm{~F}$ & 0.40 & 0.18 & $\mathbf{- 0 . 7 3}$ & $\mathbf{0 . 0 0 8}$ & 0.40 & 0.18 & 0.39 & 0.23 & -0.09 & 0.74 & 0.37 & 0.26 \\
BLP31 & $\mathrm{M}$ & $\mathbf{0 . 6 1}$ & $\mathbf{0 . 0 1 8}$ & -0.13 & 0.69 & $\mathbf{- 0 . 5 1}$ & $\mathbf{0 . 0 0 8}$ & -0.26 & 0.35 & -0.35 & 0.25 & -0.38 & 0.21 \\
BLP34 & $\mathrm{M}$ & $\mathbf{0 . 6 2}$ & $\mathbf{0 . 0 1 8}$ & -0.19 & 0.53 & $\mathbf{- 0 . 5 4}$ & $\mathbf{0 . 0 0 5}$ & -0.28 & 0.35 & -0.36 & 0.21 & -0.33 & 0.24 \\
BLP35 & $\mathrm{M}$ & $\mathbf{0 . 6 7}$ & $\mathbf{0 . 0 0 9}$ & -0.16 & 0.63 & $\mathbf{- 0 . 4 9}$ & $\mathbf{0 . 0 1 1}$ & -0.30 & 0.29 & -0.41 & 0.15 & -0.32 & 0.29 \\
BLP37 & $\mathrm{M}$ & $\mathbf{0 . 5 5}$ & $\mathbf{0 . 0 2 1}$ & -0.20 & 0.48 & $\mathbf{- 0 . 4 8}$ & $\mathbf{0 . 0 1 9}$ & -0.38 & 0.21 & -0.36 & 0.21 & -0.29 & 0.34 \\
BLP38 & $\mathrm{M}$ & $\mathbf{0 . 6 0}$ & $\mathbf{0 . 0 2 3}$ & -0.15 & 0.58 & $\mathbf{- 0 . 4 7}$ & $\mathbf{0 . 0 0 1}$ & -0.24 & 0.35 & -0.35 & 0.21 & -0.24 & 0.34 \\
BLP39 & $\mathrm{M}$ & $\mathbf{0 . 6 3}$ & $\mathbf{0 . 0 1 1}$ & -0.24 & 0.39 & $\mathbf{- 0 . 5 1}$ & $\mathbf{0 . 0 0 8}$ & -0.25 & 0.34 & -0.36 & 0.21 & -0.28 & 0.35 \\
\hline
\end{tabular}

of the SST. The expected seasonal variation of approximately $0.11 \%$ of $\delta^{18} \mathrm{O}$ in seawater $(0.43 \mathrm{psu})$ represents $29.72 \%$ of $\delta^{18} \mathrm{O}$ seasonal variation in female colonies, and $38.53 \%$ in male colonies.

The departure from isotope equilibrium of our samples was estimated with the equations by Grossman and $\mathrm{Ku}$ (1986), for $\delta^{18} \mathrm{O}$, and Romanek et al. (1992) for $\delta^{13} \mathrm{C}$. We found that the theoretical $\delta^{18} \mathrm{O}$ value of coral aragonite that precipitates at equilibrium with seawater is $-0.65 \%$, which means that our samples of coral have an average departure from isotope equilibrium of $\sim 3.54 \%$ in females, and $\sim 3.80 \%$ in males. For $\delta^{13} \mathrm{C}$, we found a theoretical value of $-1.15 \%$ for coral aragonite that precipitates at equilibrium with seawater. This means that average departure from isotope equilibrium is $\sim 2.81$ in females, and $\sim 2.53 \%$ o in males.

We found a positive relationship between skeletal $\delta^{18} \mathrm{O}$ and $\delta^{13} \mathrm{C}$ in our data. Swart et al. (1996b) suggest that this means that the maximum photoperiod in Bahía de La Paz occurs during winter (high $\delta^{18} \mathrm{O}=$ low SST, high $\delta^{13} \mathrm{C}=$ high photosynthesis). When the SST peaks in the summer and surface seawater generally becomes depleted in nutrients, zooxanthellae disperse (Hoegh-Guldberg, 1999; Barton and Casey, 2005). Hence, photosynthesis might be less intense until the nutrient-rich waters of winter promote the growth of zooxanthellae and restore photosynthesis intensity (Jokiel, 2004; Franklin et al., 2006).

Skeletal $\delta^{13} \mathrm{C}$ (Fig. 4) was higher in both sexes between November and January (lowest SST and PAR), and lower from June through August (highest SST and PAR), suggesting a positive relationship between $\delta^{13} \mathrm{C}$ and photosynthesis, and a dominant role of light-induced photosynthesis on seasonal changes of $\delta^{13} \mathrm{C}$ in coral. Still, the $\delta^{13} \mathrm{C}-\mathrm{PAR}$ correlations were not significant, thus, photosynthesis was not stimulated or inhibited by light, and remained near its maximum efficiency during the whole year, according to Sun et al. (2008). Other factors may be affecting photosynthesis in addition to light, such as abundance of dissolved nutrients. High concentrations of chlorophyll $a$ occurred during periods of enrichment of ${ }^{13} \mathrm{C}$ in the coral skeleton (November through January); however, the correlations of skeletal $\delta^{13} \mathrm{C}$ and chlorophyll $a$ were not significant in any case.

Trends in coral skeletal $\delta^{13} \mathrm{C}$ reflect seasonal variations in photosynthesis to respiration ratios in the $\delta^{13} \mathrm{C}$ pool of coral (McConnaughey, 1989; McConnaughey et al., 1997). Respiration normally increases with temperature and lowers ${ }^{13} \mathrm{C}$ in coral skeletons, which is reflected in our results, high $\mathrm{SST}=$ low $\delta^{13} \mathrm{C}$. No other environmental variables considered in this work explained this pattern in coral $\delta^{13} \mathrm{C}$, driven mainly by metabolic effects as described by Sun et al. (2008) in Porites coral of the South China Sea.

We found a negative correlation $(r=-0.78, p=0.001)$ between $\delta^{18} \mathrm{O}$ and the skeletal density in female colonies, this is not consistent with studies that have observed that coral skeletal high-density bands are enriched in ${ }^{18} \mathrm{O}$ (Klein et al., 1992; Al-Rousand, 2007). This may be due to a difference in timing of skeletal density bands in Porites coral species, as described by Lough and Barnes (2000). In male coral, we found a negative correlation between the $\delta^{18} \mathrm{O}$ and linear extension and calcification rates $(r=-0.50, p=0.045$ and $r=-0.44, p=0.0008$ ), this is consistent with the observations of other authors of Porites spp. coral (McConnaughey, 1989; Felis et al., 2003). In Porites corals, skeletal extension and calcification rates increases with SST, while skeletal density decreases (Lough and Barnes, 2000), so growth parameters of both sexes and $\delta^{18} \mathrm{O}$ behave as expected. No significant correlation was found between skeletal $\delta^{13} \mathrm{C}$ and skeletal growth parameters in either males or females, meaning that regardless of the skeletal extension rate, density or calcification rate, $P$. panamensis deposited a widely varying $\delta^{13} \mathrm{C}$, as reported by Allison et al. (1996) in Porites coral from South Thailand, and by Swart et al. (1996b) in Montastrea annularis in Florida, USA. 
General consensus states that all coral skeletons contain appreciable amounts of carbon and oxygen in isotopic disequilibrium, and are depleted in ${ }^{18} \mathrm{O}$ and ${ }^{13} \mathrm{C}$ because of kinetic variations due to differences in coral growth. McConnaughey (1989) named this phenomenon "vital effect". We found this to be true for all sampled coral (disequilibrium $=3.54 \% \circ \mathrm{F}, 3.80 \% \circ \mathrm{M}$ in $\delta^{18} \mathrm{O} ; 2.81 \% \circ \mathrm{F}, 2.53 \% \circ \mathrm{M}$ in $\left.\delta^{13} \mathrm{C}\right)$. McConnaughey (1989) considers kinetic depletion as a constant in coral with fast extension rates $\left(>0.5 \mathrm{~cm} \mathrm{yr}^{-1}\right)$. The average yearly extension rates of all sampled coral can be considered as fast $\left(1.05 \mathrm{~cm} \mathrm{yr}^{-1} \mathrm{~F}\right.$, and $\left.1.27 \mathrm{~cm} \mathrm{yr}^{-1} \mathrm{M}\right)$ in accordance with the work of McConnaughey (1989). Thus, we assume kinetic disequilibrium is constant in all coral.

All $\delta^{18} \mathrm{O}$ ratios of female colonies are more enriched in ${ }^{18} \mathrm{O}$ than in male colonies, with an average difference of $\sim 0.31 \%$. Female $\delta^{13} \mathrm{C}$ values were lower than the $\delta^{13} \mathrm{C}$ of male colonies, with an average difference of $\sim 0.28 \%$. All coral colonies in our study grew and calcified in the same environmental conditions. Thus, differences in the isotope record between coral growing in the same environment are attributed to differences in the "vital effect" of each colony (Linsley et al., 1999; Felis et al., 2003).

Linsey et al. (1999) found differences of $0.4 \%$ in the $\delta^{18} \mathrm{O}$ records of six Porites lobata coral living in nearly identical environments at Clipperton atoll. Felis et al. (2003) found a $1.28 \%$ difference in the $\delta^{18} \mathrm{O}$ records of 11 coral of several Porites species, in three sites in the northern part of the Gulf of Aqaba. None of the mentioned works considered the sex of the colony as a factor explaining differences in the "vital effect" of coral colonies. If we pool the isotopic data of both sexes together, the differences between our isotopic records are $0.38 \%$ in the $\delta^{18} \mathrm{O}$ record, and $0.29 \%$ in the $\delta^{13} \mathrm{C}$ record. If we split our data by sex, the differences in the isotopic records drop to $0.07 \%$ in the $\delta^{18} \mathrm{O}$, and to $0.02 \%$ o in the $\delta^{13} \mathrm{C}$. In our data, the sex of the colony explains $81 \%$ $\left(\delta^{18} \mathrm{O}\right)$ and $93 \%\left(\delta^{13} \mathrm{C}\right)$ of the differences in the "vital effect" of coral colonies. Thus, the main source of differences in the isotope record is attributed to differences in the "vital effect" associated with colony sex, for which we offer two explanations; a simple one, and a complex one.

Energy expenditure during the formation of gametes causes differences in the formation of skeletal density bands, and carbon isotopic depletion in coral skeletons (Kramer et al., 1993; Gagan et al., 1994). Cabral-Tena et al. (2013), and Carricart-Ganivet et al. (2013) found sex-dependent effects on the growth parameters and timing of density band formation of coral, related to metabolic effects. We found that $P$. panamensis female colonies grew slower in comparison to male colonies $\left(1.05 \pm 0.04 \mathrm{~cm} \mathrm{yr}^{-1}\right.$ vs. $\left.1.27 \pm 0.04 \mathrm{~cm} \mathrm{yr}^{-1}\right)$. Faster growing coral are more depleted in ${ }^{18} \mathrm{O}$ and more enriched in ${ }^{13} \mathrm{C}$, relative to slower-growing coral (McConnaughey, 1989; Felis et al., 2003), this may be the origin of the isotope data difference between sexes (higher $\delta^{18} \mathrm{O}$ and lower $\delta^{13} \mathrm{C}$ in females), so a simplistic approach might be that since the growth rates are different between sexes, the "vital effect" will also be different between sexes, thus explaining the differences we found in $\delta^{18} \mathrm{O}$ and $\delta^{13} \mathrm{C}$ between sexes.

A more complex explanation for this sex-associated difference in coral isotopic data could result from the role $\mathrm{Ca}$ ATPase (enzyme strongly associated with coral calcification) activity has in the mechanism of the "vital effect". Adkins et al. (2003), and Rollion-Bard et al. (2003) found that the CaATPase activity in deep sea and symbiotic coral establishes a pH gradient between the coral cell wall and the extracellular calcifying fluid (ECF). The $\mathrm{pH}$ gradient (more basic in the $\mathrm{ECF}$ ) promotes a passive $\mathrm{CO}_{2}$ flux into the ECF and controls the mixing of carbon with isotopically heavier signature from the seawater-dissolved inorganic carbon, thus, the intense activity of Ca-ATPase will result in a carbon heavier skeleton. Oxygen isotopes also respond to the $\mathrm{pH}$ of the ECF as proportions of the dissolved carbonate species are $\mathrm{pH}$ dependent. At low $\mathrm{pH}$ the dominant species is $\mathrm{H}_{2} \mathrm{CO}_{3}$, at intermediate $\mathrm{pH}$ it is $\mathrm{HCO}_{3}^{-}$, and at high $\mathrm{pH}, \mathrm{CO}_{2}^{3-}$ is the dominant species. McCrea (1950) demonstrated that the $\delta^{18} \mathrm{O}$ of carbonates is related to the proportion of $\mathrm{HCO}_{3}^{-}$and $\mathrm{CO}_{2}^{3}$ in the solution $\left(\mathrm{CO}_{2}^{3-}\right.$ is isotopically lighter). Thus, $\mathrm{pH}$ controls the relative fractions of dissolved $\mathrm{HCO}_{3}^{-}$and $\mathrm{CO}_{2}^{3}$ in the $\mathrm{ECF}$ and the kinetics of their isotopic equilibration with water, before carbonate precipitation. An intense activity of CaATPase will result in oxygen-lighter skeletons. According to this theory, a higher activity of the Ca-ATPase enzyme will result in carbon-heavier skeletons and oxygen-lighter skeletons. Cohen and Holcomb (2009) mention that the activity of ATPase depends on the amount of energy available for the calcification for coral. Cabral-Tena et al. (2013) suggest it is possible that male $P$. panamensis have more available energy for calcification, which would mean males have a higher activity of the Ca-ATPase, which results in enriched $\mathrm{C}^{13}$ and depleted $\mathrm{O}^{18}$ skeletons, in comparison to female skeletons, as seen in our data $\left(-1.66 \%\right.$ F vs. $-1.38 \%$ M $\delta \mathrm{C}^{13} ;-2.89 \%$ o F vs. $-3.20 \%$ o $\left.\mathrm{M} \delta \mathrm{O}^{18}\right)$. This complex mechanism of the origin of the "vital effect" might explain why we found a sex-associated variation in coral skeletal oxygen and carbon isotopic composition of Porites panamensis.

Kramer et al. (1993), and Gagan et al. (1994) suggested that energy expenditure during the formation of gametes may cause differences in the isotopic depletion in coral skeletons; Kramer et al. (1993) observed depletions in isotope data during reproductive seasons, regardless of the sex of the coral, and found minimum $\delta^{13} \mathrm{C}$ values in skeletons of Oribicella faveolata during spawning seasons (summer), although this phenomenon was also observed in other coral species which produce gametes the whole year ( $O$. faveolata has only one reproductive event per year). The results obtained by Kramer et al. (1993) were inconclusive, but suggested a lag effect of isotope signal, associated with the initiation and duration of the reproductive cycle. It is possible that the sex-associated variation we found in isotope data is due to the reproduc- 
tive strategy of $P$. panamensis. $P$. panamensis is a gonochoric brooding species with reproductive and larval release events through the whole year in the Pacific coast of Mexico (Carpizo-Ituarte et al., 2011; Rodriguez-Troncoso et al., 2011). Energy costs of reproduction in gonochoric spawners are lower than in gonochoric brooding species where energy is required not only for egg production, but also for larval development (Szmant, 1986). This implies that there should be sex-associated variations in the coral skeletal isotope data of other gonochoric brooding coral, as some massive Porites (which can be spawners or brooders; Glynn et al., 1994; Baird et al., 2009).

We found some interesting results when applying the Heikoop et al. (2000) correction factor to isolate the kinetic and metabolic effects in the $\delta^{13} \mathrm{C}$ of male and female colonies. Both transformed $\delta^{13} \mathrm{C}$ and metabolic $\delta^{13} \mathrm{C}$ seem to be higher in males, thus supporting the hypothesis stating that an intense activity of the Ca-ATPase enzyme will result in a carbon-heavier skeleton. Ca-ATPase enzyme activity is related positively to energy availability in corals (Cohen and Holcomb, 2009), so it would explain why both kinetic effect (skeletal growth) and metabolic effect (coral photosynthesis/respiration) are higher in male corals, since male corals grow faster than female colonies.

Considering $\delta^{18} \mathrm{O}$ of coral skeletons is used to estimate SST in different sites and conditions, the next part of the discussion seeks to exemplify what a difference in $\delta^{18} \mathrm{O}$ between sexes would represent in terms of errors in SST estimation. Using the widely accepted paleotemperature equations for calcite (Epstein et al., 1953) and aragonite (Grossman and $\mathrm{Ku}, 1986$ ), a $\sim 0.31 \%$ difference between sexes would represent an error in SST estimates of $\sim 1.47$ and $\sim 1.33^{\circ} \mathrm{C}$. Using accepted SST-coral $\delta^{18} \mathrm{O}$ relationships from different regions of the Pacific, derived from Porites spp., the $\delta^{18} \mathrm{O}$ difference between sexes would represent an error of $\sim 1.75$ (Red Sea; Al-Rousand et al., 2003), 1.71 (Great Barrier Reef; Gagan et al., 1994), 1.31 (Costa Rica; Carriquiry, 1994), 1.39 (Central and Eastern Tropical Pacific; Druffel, 1985), 1.47 (The Galapagos; McConnaughey, 1989), and $\sim 1.47^{\circ} \mathrm{C}$ in SST estimates, for the commonly used paleotemperature calibration in coral $\left(0.21 \%{ }^{\circ} \mathrm{C}^{-1}\right)$.

$\delta^{13} \mathrm{C}$ of coral skeletons has been used as a proxy for the photosynthetic activity of zooxanthellae (mainly driven by light). Until now, no general rule applies to how much $\delta^{13} \mathrm{C}$ means how much radiance (like the dependence of $\delta^{18} \mathrm{O}$ to SST resulting in paleotemperature equations), but a difference of $\sim 0.28 \%$ in coral $\delta^{13} \mathrm{C}$ between sexes should be taken into account for this kind of application, since it may influence the descriptions of the variability in $\delta^{13} \mathrm{C}$ of coral skeletons. $\delta^{13} \mathrm{C}$ of coral skeletons is also used to correct the $\delta^{18} \mathrm{O}$ data when estimating the SST at which coral grew, by using the regression line equations obtained from the $\delta^{13} \mathrm{C}$ vs. $\delta^{18} \mathrm{O}$ plots (Smith et al., 2000). When we compared the regression line equations obtained from the $\delta^{13} \mathrm{C}$

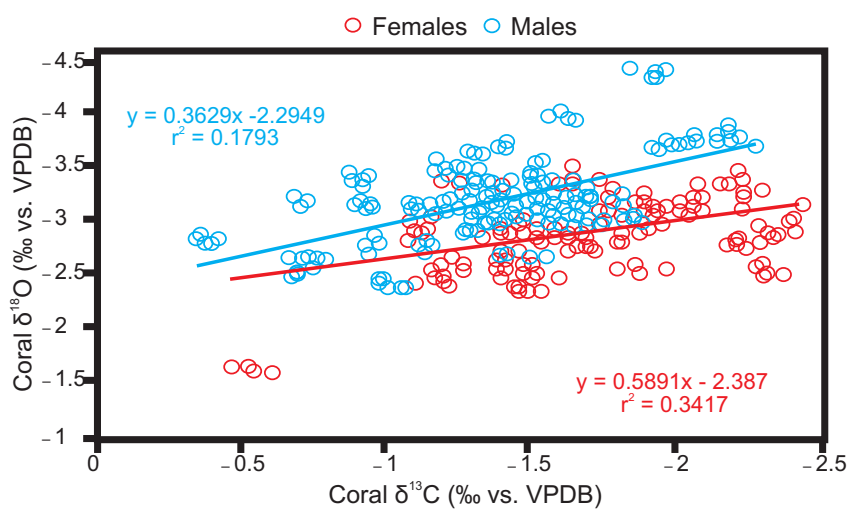

Figure 6. Plot of $\delta^{13} \mathrm{C}$ vs. $\delta^{18} \mathrm{O}$ of female (red dots), and male (blue dots) Porites panamensis coral from Bahía de La Paz. This includes all isotopic data of all colonies. Line equations and coefficients (red represents females; blue represents males) are shown.

vs. $\delta^{18} \mathrm{O}$ plots of both sexes, the ANCOVA showed that both the slope $\left(F_{498}=9.619, p=0.002\right)$ and the $y$ intercept $\left(F_{498}=222.5, p<0.00001\right)$ are different between equations (Fig. 6). Also, Fisher's $r$-to- $z$ transformation $(z=-2.34$, $p=0.01)$ showed that the $\delta^{13} \mathrm{C}$ vs. $\delta^{18} \mathrm{O}$ correlation coefficients are significantly different between sexes, i.e. the relationship in $\delta^{13} \mathrm{C}$ vs. $\delta^{18} \mathrm{O}$ is different in both sexes; this has important implications because it could add a variability source to the use of the $\delta^{13} \mathrm{C}$ vs. $\delta^{18} \mathrm{O}$ regression line as corrector for $\delta^{18} \mathrm{O}$ data, if the sex of the colony is not taken into account in the analysis.

This study provides evidence of sex-associated variations in coral skeletal $\delta^{18} \mathrm{O}$ and $\delta^{13} \mathrm{C}$ of $P$. panamensis. This has some implications and has to be considered when climate conditions are estimated based on comparisons of $\delta^{18} \mathrm{O}$ and $\delta^{13} \mathrm{C}$ values of gonochoric brooder coral genera, if sex identification is not taken into account when possible. The findings of this study are based on a gonochoric brooder species $(P$. panamensis), the majority of paleoclimatic reconstructions in the Indo-Pacific and Caribbean have been based on massive gonochoric spawners (such as Montastrea cavernosa, Porites lutea and Porites lobata), so, it remains unclear if the same phenomena (sex-associated variations in coral skeletal $\delta^{18} \mathrm{O}$ and $\delta^{13} \mathrm{O}$ ) can be observed in gonochoric spawners, this may have some serious implications in the paleoclimatic reconstructions studies made so far leading to erroneous conclusions due to errors in isotopic estimation, variability of isotopic data may have been overestimated due to the mixing of male and female isotopic data in past studies. Thus, a fruitful area of future research would be to determine whether the sex differences identified in this study are also characteristic of gonochoric spawners. 


\section{Data availability}

Monthly SST, PAR, and concentration of chlorophyll a records are respectively available at http://coastwatch. pfeg.noaa.gov/erddap/griddap/erdMBsstd1day.html, http://coastwatch.pfeg.noaa.gov/erddap/griddap/ erdMH1par0mday.html and http://coastwatch.pfeg.noaa. gov/erddap/griddap/erdMBchlamday.html. Monthly rainfall data are accessible from the Servicio Meteorológico Nacional at http://clicom-mex.cicese.mx/mapa.html, data from the 3074-LA PAZ (DGE), BCS climatological station were used.

Author contributions. Rafael A. Cabral-Tena and Eduardo F. Balart conceived and designed the study; Rafael A. Cabral-Tena, Angel H. Ruvalcaba-Díaz and AS processed isotopically the material. Rafael A. Cabral-Tena, AS, Héctor Reyes-Bonilla and Eduardo F. Balart analyzed the data. All authors discussed the results and wrote the manuscript.

Acknowledgements. We thank Carmen Rodríguez-Jaramillo and Eulalia Meza-Chávez for assisting with histological procedures; Ira Fogel and Carlos Ruiz provided editorial services; Mario Cota, David Paz, and Alejandro Aldana assisted in the field work; Carlos Soto Carrasco and Jorge Cobos Anaya helped prepare coral material; Luis E. Calderón Aguilera and Carlos Orión Norzagaray López assisted in the X-radiographand; and Noemi Bocanegra assisted in the laboratory. All are at CIBNOR. This project was funded by CIBNOR project EP0.02 and SEPCONACYT grant 157993. Rafael A. Cabral-Tena is a recipient of a fellowship from CONACYT (212435).

Edited by: S. W. A. Naqvi

\section{References}

Adkins, J. F., Boyle, E. A., Curry, W. B., and Lutringer, A.: Stable isotopes in deep-sea corals and a new mechanism for "vital effects", Geochim. Cosmochim. Acta, 67, 1129-1143, 2003.

Allison, N., Tudhope, A. W., and Fallick, A. E.: Factors influencing the stable carbon and oxygen isotopic composition of Porites lutea coral skeletons from Phuket, South Thailand, Coral Reefs, 15, 43-57, 1996.

Al-Rousand, S., Felis, T., Manasrah, R., and Al-Horani, F.: Seasonal variations in the stable oxygen isotopic composition in Porites corals from the northern Gulf of Aqaba, Red Sea, Geochem. J., 41, 333-340, 2007.

Asami, R., Yamada, T., Iryu, Y., Meyer, C. P., Quinn, T., and Paulay, G.: Carbon and oxygen isotopic composition of a Guam coral and their relationship to environmental variables in the western Pacific, Palaeogeogr. Palaeoecol., 212, 1-22, 2004.

Baird, A. H., Guest, J. R., and Willis, B. L.: Systematic and biogeographical patterns in the reproductive biology of scleractinian corals, Ann. Rev. Ecol. Syst., 40, 531-571, 2009.
Barnes, D. J. and Lough, J. M.: Systematic variations in the depth of skeleton occupied by coral tissue in massive colonies of Porites from the Great Barrier Reef, J. Exp. Mar. Biol. Ecol., 159, 113128, 1992.

Barnes, D. J., Taylor, R. B., and Lough, J. M.: On the inclusion of trace materials into massive coral skeletons. Part II: distortions in skeletal records of annual climate cycles due to growth processes, J. Exp. Mar. Biol. Ecol., 194, 251-275, 1995.

Barton, A. D. and Casey, K. S.: Climatological context for large scale bleaching, Coral Reefs, 24, 536-554, 2005.

Bernal, G. R. and Carriquiry, J. D.: Stable isotope paleoenvironental record of a coral from Cabo Pulmo, entrance to the Gulf of California, Mexico, Cienc. Mar., 27, 155-174, 2001.

Cabral-Tena, R. A., Reyes-Bonilla, H., Lluch-Cota, S., Paz-Garcia, D. A., Calderon-Aguilera, L. E., Norzagaray-Lopez, O., and Balart, E. F.: Different calcification rates in males and females of the coral Porites panamensis in the Gulf of California, Mar. Ecol. Prog. Ser., 476, 1-8, 2013.

Carpizo-Ituarte, E., Vizcaíno-Ochoa, V., Chi-Barragán, G., TapiaVázquez, O., Cupul-Magaña, A. L., and Medina-Rosas, P.: Evidence of sexual reproduction in the hermatypic corals Pocillopora damicornis, Porites panamensis, and Pavona gigantea in Banderas Bay, Mexican Pacific, Cienc. Mar., 37, 97-112, 2011.

Carricart-Ganivet, J. P. and Barnes, D. J.: Densitometry from digitized images of X-radiographs: methodology for measurement of coral skeletal density, J. Exp. Mar. Biol. Ecol., 344, 67-72, 2007.

Carricart-Ganivet, J. P., Vásquez-Bedoya, L.F., Cabanillas-Terán, N., and Blanchon, P.: Gender-related differences in the apparent timing of skeletal density bands in the reef-building coral Siderastrea sidera, Coral Reefs, 32, 769-777, 2013.

Carriquiry, J. D.: ${ }^{18} \mathrm{O}$ Fractionation in the coralline aragonite of Porites lobata: Implications in oceanic paleothermometry studies, Cienc. Mar., 20, 585-606, 1994.

Carriquiry, J. D., Risk, M. J., and Schwarcz, H. P.: Stable isotope geochemistry of corals from Costa Rica as proxy indicator of the El Niño/Southern Oscillation (ENSO), Geochim. Cosmochim. Acta, 58, 335-351, 1994.

Charles, C. D., Hunter, D. E., and Fairbanks, R. G.: Interaction between the ENSO and the Asian monsoon in a coral record of tropical climate, Science, 277, 925-928, 1997.

CLICOM: daily climatic data from of the SMN with CICESE graphs, http://clicom-mex.cicese.mx, 2015.

Cohen, A. L. and Hart, S. R.: The effect of colony topography on climate signals in coral skeleton, Geochim. Cosmochim. Acta, 61, 3905-3912, 1997.

Cohen, A. L. and Holcomb, M.: Why corals care about ocean acidification uncovering the mechanism, Oceanography, 22, 118-127, 2009.

Cole, J. E. and Fairbanks, R. G.: The Southern Oscillation recorded in the $\delta^{18} \mathrm{O}$ of corals from Tarawa Atoll, Paleoceanography, 5, 669-683, 1990.

Cole, J. E., Fairbanks, R. G., and Shen, G. T.: Recent variability in the southern oscillation: isotopic results from a Tarawa atoll coral, Science, 260, 1790-1793, 1993.

Druffel, E. R. M.: Detection of El Niño and decade time scale variations of sea surface temperature from banded coral records: Implications for the carbon dioxide cycle, in: The carbon cycle and atmospheric $\mathrm{CO}$ natural variations, Archea to presen, edited 
by: Sundquist E. T. and Broecker, W. S., American Geophysical Union, Washington, DC, doi:10.1029/GM032p0111, 1985.

Druffel, E. R. M.: Geochemestry of corals: proxies of past ocean chemistry, ocean circulation, and climate, P. Natl. Acad. Sci. USA, 94, 8354-8361, 1997.

Dunbar, R. G. and Wellington, G. M.: Stable isotopes in a branching coral monitor seasonal temperature variation, Nature, 293, 453455, 1981.

Dunbar, R. G., Wellington, G. M., Colgan, M. W., and Glynn, P. W.: Eastern Pacific sea surface temperature since 1600 A.D.: the $\delta^{18} \mathrm{O}$ record of climate variability in Galapagos corals, Paleoceanography, 9, 291-315, 1994.

Epstein, S., Buschbaum, R., Lowenstam, H. A., and Urey, H. C.: Revised carbonate-water isotopic temperature scale, Geol. Soc. Am. Bull., 64, 1315-1325, 1953.

Fairbanks, R. G., Evans, M. N., Rubenstone, J. L., Mortlock, R. A., Broad, K., Moore, M. D., and Charles, C. D.: Evaluating climate indices and their geochemical proxies measured in corals, Coral Reefs, 16, S93-S100, 1997.

Felis, T., Patzold, J., Loya, Y., and Wefer, G.: Vertical water mass mixing and plankton blooms recorded in skeletal stable carbon isotopes of a Red Sea coral, J. Geophys. Res., 103, 730-739, 1998.

Felis, T., Pätzold, J., and Loya, Y.: Mean oxygen-isotope signatures in Porites spp. corals: inter-colony variability and correction for extension-rate effects, Coral Reefs, 22, 328-336, 2003.

Franklin, D. J., Cedrés, C., and Hoegh-Guldberg, O.: Increased mortality and photoinhibition in the symbiotic dinoflagellates of the Indo-Pacific coral Stylophora pistillata (Esper) after summer bleaching, Mar. Biol., 149, 633-642, 2006.

Gagan, M. K., Chivas, A. R., and Isdale, P. J.: High-resolution isotopic records from corals using ocean temperature and massspawning chronometers, Earth Planet. Sc. Lett., 121, 249-258, 1994.

Gagan, M. K., Ayliffe, L. K., Beck, J. W., Cole, J. E., Druffel, E. R. M., Dunbar, R. B., and Schrag, D. P.: New views of tropical paleoclimates from corals, Quaternary Sci. Rev., 19, 45-64, 2000.

Glynn, P. W., Colley, S. B., Eakin, C. M., Smith, D. B., Cortés, J., Gassman, N. J., Guzmán, H. M., Del Rosario, J. B., and Feingold, J. S.: Reef coral reproduction in the eastern Pacific: Costa Rica, Panamá and the Galápagos Islands (Ecuador), II. Poritidae, Mar. Biol., 118, 191-208, 1994.

Grossman, E. L. and Ku T. L.: Oxygen and carbon isotope fractionation in biogenic aragonite: temperature effects, Chem. Geol., 59, 59-74, 1986.

Grottoli, A. G. and Eakin, C. M.: A review of modern coral $\delta^{18} \mathrm{O}$ and $\Delta^{14} \mathrm{C}$ proxy records, Earth-Sci. Rev., 81, 67-91, 2007.

Grottoli, A. G. and Wellington, G. M.: Effect of light and zooplankton on skeletal $\delta^{13} \mathrm{C}$ values in the eastern Pacific corals Pavona clavus and Pavona gigantean, Coral Reefs, 18, 29-41, 1999.

Guzmán, H. M. and Cortés, J.: Growth rates of eight species of scleractinian corals in the eastern Pacific (Costa Rica), Bull. Mar. Sci., 44, 1186-1194, 1989.

Halfar, J., Godinez-Orta, L., Rieg, B. J., Valdez-Holguin, E., and Borges, J. M.: Living on the edge: high-latitude Porites carbonate production under temperate eutrophic conditions, Coral Reefs, 24, 582-592, 2005.

Heikoop, J. M., Dunn, J. J., Risk, M. J., Schwarcz, H. P., McConnaughey, T. A., and Sandeman, I. M.: Separation of kinetic and metabolic isotope effects in carbon-13 records preserved in reef coral skeletons, Geochim. Cosmochim. Acta, 64, 975-987, 2000.

Hoegh-Guldberg, O.: Climate change, coral bleaching and the future of the world's coral reefs, Mar. Freshw. Res., 50, 839-866, 1999.

Hönisch, B., Hemming, N. G., Grottoli, A. G., Amat, A., Hanson, G. N., and Bijma, J.: Assessing scleractinian corals as recorders for paleo-pH: empirical calibration and vital effects, Geochim. Cosmochim. Acta, 68, 3675-3685, 2004.

Howard, D. W. and Smith, C. S.: Histological techniques for marine bivalve mollusks. NOAA Tech Memo NMFSF/NEC-25, US Department of Commerce, Woods Hole, MA, 1983.

Hudson, J. H., Shinn, E. A., Halley, R. B., and Lidz, B.: Sclerochronology: A tool for interpreting past environments, Geology, 4, 361-364, 1976.

Humason, G. L.: Animal tissue techniques, W. H. Freeman, San Francisco, 1979.

Jokiel, P. L.: Temperature stress and coral bleaching, in: Coral Health and Disease, edited by: Rosenberg, E. and Loya, Y., Springer-Verlag, Heidelberg, 401-425, 2004.

Klein, R., Pätzold, J., Wefer, G., and Loya, Y.: Seasonal variation in the stable isotopic composition and skeletal density pattern of the coral Porites lobata (Gulf of Eliat, Red Sea), Mar. Biol., 112, 259-263, 1992.

Kramer, P. A., Swart, P. K., and Szmant, A. M.: The influence of different sexual reproductive patterns on density banding and stable isotopic compositions of corals, Proceedings of the 7th International Coral Reef Symposium, Guam, 1, p. 222, 1993.

Land, L. S, Lang, J. C., and Barnes, D. J.: Extension rate a primary control on the isotopic composition of West Indian (Jamaican) scleractinian reef coral skeletons, Mar. Biol., 33, 221-233, 1975.

Le Bec, N., Julliet-Leclere, A., Corrége, T., Blamart, D., and Delcroix, T.: A coral $\delta^{18} \mathrm{O}$ of ENSO driven sea surface salinity variability in Fiji (south-western tropical Pacific). Geophys. Res. Lett., 27, 387-3900, 2000

Linsley, B. K., Dunbar, R. B., Wellington, G. M., and Mucciarone, D. A.: A coral-based reconstruction of intertropical convergence zone variability over Central America since 1707, J. Geophys. Res., 99, 9977-9994, 1994.

Linsley, B. K., Messier, R. G., and Dunbar, R. B.: Assessing between-colony oxygen isotope variability in the coral Porites lobata at Clipperton Atoll, Coral Reefs, 18, 13-27, 1999.

Lough, J. M. and Barnes, D. J.: Environmental controls on growth of the massive coral Porites, J. Exp. Mar. Biol. Ecol., 245, 225243, 2000.

Lough, J. M. and Cooper, T. F.: New insights from coral growth band studies in an era of rapid environmental change, Earth-Sci. Rev., 108, 170-184, 2011.

Lough, J. M., Barnes, D. J., and Taylor, R. B.: The potential of massive corals for the study of high-resolution climate variations in the past millennium, in: Climate variations and forcing mechanisms of the last 2000 years, edited by: Jones, P. D., Bradley, R. S., and Jouzel, J., Pub NATO Advanced Research Workshop series, Springer-Verlag, Berlin, 357-373, 1996.

McConnaughey, T. A.: ${ }^{13} \mathrm{C}$ and ${ }^{18} \mathrm{O}$ disequilibrium in biological carbonates: I Patterns, Gechim. Cosmochim. Acta, 53, 151-162, 1989. 
McConnaughey, T. A., Burdett, J., Whelan, J. F., and Paull, C. K.: Respiration and photosynthesis: Effects on the carbon- 13 content of biological carbonates, Geochim. Cosmochim. Acta, 61, 611622,1997

McCrea, J. M.: On the isotopic chemistry of carbonates and a paleotemperature scale, J. Chem. Phys., 18, 849-857, 1950.

Obeso-Niebla, M., Shirasago-Germán, B., Gaviño-Rodríguez, J. H., Obeso-Huerta, H., Pérez-Lezama, E. L., and Jiménez-Illescas, A. R.: Hydrography at the north mouth of La Paz Bay, Baja California Sur, México, Cienc. Mar., 33, 281-291, 2007.

Omata, T., Suzuki, A., Sato, T., Minoshima, K., Nomaru, E., Murakami, A., Murayama, S., Kawahata, H., and Maruyama, T.: Effect of photosynthetic light dosage on carbon isotope composition in the coral skeleton: Long-term culture of Porites spp., J. Geophys. Res., 113, G02014, doi:10.1029/2007JG000431, 2008.

Quinn, T. M., Taylor, F. W., and Crowley, T. J.: A 173 year stable isotope record from a tropical south Pacific coral, Quaternary Sci. Rev., 12, 407-418, 1993.

Reyes-Bonilla, H., González-Romero, S., Cruz-Piñón, G., and Calderón-Aguilera, L. E.: Corales pétreos, in: Bahía de los Ángeles: recursos naturales y comunidad, edited by: Danemann, G. and Ezcurra, E., Línea Base 2007, Secretaria de Medio Ambiente y Recursos Naturales, PRONATURA, Instituto Nacional de Ecología, San Diego Natural History Museum, Ensenada, Mexico, 291-318, 2007.

Rodionov, S. N.: A sequential algorithm for testing climate regime shifts, Geophys. Res. Lett., 31, L09204, doi:10.1029/2004GL019448, 2004.

Rodríguez-Troncoso, A. P., Carpizo-Ituarte, E., Leyte-Morales, G. E, Chi-Barragán, G., and Tapia-Vázquez, O.: Sexual reproduction of three coral species from the Mexican South Pacific, Mar. Biol., 158, 2673-2683, 2011.

Rollion-Bard, C., Chaussidon, M., and France-Lanord, C.: pH control on oxygen isotopic composition of symbiotic corals, Earth. Planet. Sc. Lett., 215, 275-288, 2003.

Romanek, C. S., Grossman, E. L., and Morse, J, W.: Carbon isotopic fractionation in synthetic aragonite and calcite: Effects of temperature and precipitation rate, Geochim. Cosmochim. Acta, 56, 419-430, 1992.

Sazzad, H. M. D., Wijaya, A. R., Tanaka, K., and Ohde, S.: Environmental effects on the stable carbon and oxygen isotopic compositions and skeletal density banding pattern of Porites coral from Khang Khao Island, Thailand, Afr. J. Biotechnol., 9, 5373-5382, 2010.

Schrag, D. P.: Rapid analysis of high-precision $\mathrm{Sr} / \mathrm{Ca}$ ratios in coral and other marine carbonates, Paleoceanography, 14, 97$102,1999$.
Sicard-González, M. T., Tripp-Valdéz, M. A., Ocampo, L., MaedaMartínez, A. N., and Lluch-Cota, S. E.: Coastal sea surface temperature records along the Baja California Peninsula, Oceánides, 27, 65-69, 2012.

Simons, R. A.: ERDDAP, http://coastwatch.pfeg.noaa.gov/erddap, Monterey, CA, NOAA/NMFS/SWFSC/ERD, 2015.

Smith, J. E., Scwarcz, H. P., and Risk, M. J.: Paleotemperatures from deep-sea corals: Overcoming "vital effects", Palaios, 15, 25-32, 2000.

Sun, D., Su, R., McConnaughey, T. A., and Bloemendal, J.: Variability of skeletal growth and $\delta^{13} \mathrm{C}$ in massive corals from the South China Sea: Effect of photosynthesis, respiration and human activities, Chem. Geol., 255, 414-425, 2008.

Swart, P. K.: Carbon and oxygen isotope fractionation in scleractinian corals: a review, Earth-Sci. Rev., 19, 51-80, 1983.

Swart, P. K., Dodge, R. E., and Hudson, H. J.: A 240-year stable oxygen and carbon isotopic record in a coral from South Florida: implications for the prediction of precipitation in Southern Florida, Palaios, 11, 362-373, 1996a.

Swart, P. K., Leder, J. J., Szmant, A. M., and Dodge, R. E.: The origin of variations in the isotopic record of sclereactinian corals: II. Carbon, Geochim. Cosmochim. Acta, 60, 2871-2885, 1996b.

Szmant, A. M.: Reproductive ecology of Caribbean reef corals, Coral Reefs, 5, 43-54, 1986.

Taylor, R. B., Barnes D. J., and Lough J. M.: On the inclusion of trace materials into massive coral skeletons. 1. Materials occurring in the environment in short pulses, J. Exp. Mar. Biol. Ecol., $185,255-278,1995$

Tudhope, A. W., Lea, D. W., Shimmield, G. B., Chilcott, C. P., and Head, S.: Monsoon climate and Arabian Sea coastal upwelling recorded in massive corals from southern Oman, Palaios, 11, 347-361, 1996.

Weber, J. N. and Woodhead, P. M. J.: Temperature dependence of oxygen-18 concentration in reef coral carbonates, J. Geophys. Res., 77, 464-473, 1972.

Wellington, G. M. and Dunbar, R. B.: Stable isotopic signature of El Niño-Southern Oscillation events in eastern tropical Pacific reef corals, Coral Reefs, 14, 5-25, 1995.

Wellington, G. M., Dunbar, R. B., and Merlen, G.: Calibration of stable oxygen isotope signatures in Galapagos corals, Paleoceanography, 11, 467-480, 1996. 